\title{
Aqueous-Phase Reactive Uptake of Dicarbonyls as a Source of Organic Aerosol Over Eastern North America
}

\section{Citation}

Fu, Tzung-May, Daniel J. Jacob, and Colette L. Heald. 2009. Aqueous-phase reactive uptake of dicarbonyls as a source of organic aerosol over eastern North America. Atmospheric Environment 43(10): 1814-1822.

\section{Published Version}

doi:10.1016/j.atmosenv.2008.12.029

\section{Permanent link}

http://nrs.harvard.edu/urn-3:HUL.InstRepos:3553958

\section{Terms of Use}

This article was downloaded from Harvard University's DASH repository, and is made available under the terms and conditions applicable to Other Posted Material, as set forth at http:// nrs.harvard.edu/urn-3:HUL.InstRepos:dash.current.terms-of-use\#LAA

\section{Share Your Story}

The Harvard community has made this article openly available.

Please share how this access benefits you. Submit a story.

\section{Accessibility}




\title{
Aqueous-phase reactive uptake of dicarbonyls as a source of organic aerosol over eastern North America
}

\author{
Tzung-May Fu ${ }^{\mathrm{a}, *}$, Daniel J. Jacob ${ }^{\mathrm{a}}$, Colette L. Heald ${ }^{\mathrm{b}}$ \\ ${ }^{a}$ Department of Earth and Planetary Sciences and School of Engineering and Applied Sciences, Harvard University, Cambridge, MA, USA \\ ${ }^{\mathrm{b}}$ Department of Atmospheric Science, Colorado State University, Fort Collins, CO, USA
}

\section{A R T I C L E I N F O}

\section{Article history:}

Received 5 August 2008

Received in revised form

11 December 2008

Accepted 13 December 2008

\section{Keywords:}

Secondary organic aerosol

Glyoxal

Methylglyoxal

Organic carbon

WSOC

ICARTT

\begin{abstract}
A B S T R A C T
We use a global 3-D atmospheric chemistry model (GEOS-Chem) to simulate surface and aircraft measurements of organic carbon (OC) aerosol over eastern North America during summer 2004 (ICARTT aircraft campaign), with the goal of evaluating the potential importance of a new secondary organic aerosol (SOA) formation pathway via irreversible uptake of dicarbonyl gases (glyoxal and methylglyoxal) by aqueous particles. Both dicarbonyls are predominantly produced in the atmosphere by isoprene, with minor contributions from other biogenic and anthropogenic precursors. Dicarbonyl SOA formation is represented by a reactive uptake coefficient $\gamma=2.9 \times 10^{-3}$ and takes place mainly in clouds. Surface measurements of OC aerosol at the IMPROVE network in the eastern U.S. average $2.2 \pm 0.7 \mu \mathrm{g} \mathrm{C} \mathrm{m}^{-3}$ for July-August 2004 with little regional structure. The corresponding model concentration is $2.8 \pm 0.8 \mu \mathrm{g} \mathrm{C} \mathrm{m}^{-3}$, also with little regional structure due to compensating spatial patterns of biogenic, anthropogenic, and fire contributions. Aircraft measurements of water-soluble organic carbon (WSOC) aerosol average $2.2 \pm 1.2 \mu \mathrm{g} \mathrm{C} \mathrm{m}^{-3}$ in the boundary layer $(<2 \mathrm{~km})$ and $0.9 \pm 0.8 \mu \mathrm{g} \mathrm{C} \mathrm{m}^{-3}$ in the free troposphere $(2-6 \mathrm{~km})$, consistent with the model $\left(2.0 \pm 1.2 \mu \mathrm{g} \mathrm{C} \mathrm{m}^{-3}\right.$ in the boundary layer and $1.1 \pm 1.0 \mu \mathrm{g} \mathrm{C} \mathrm{m}^{-3}$ in the free troposphere). Source attribution for the WSOC aerosol in the model boundary layer is $27 \%$ anthropogenic, $18 \%$ fire, $28 \%$ semi-volatile SOA, and $27 \%$ dicarbonyl SOA. In the free troposphere it is $13 \%$ anthropogenic, $37 \%$ fire, $23 \%$ semi-volatile SOA, and $27 \%$ dicarbonyl SOA. Inclusion of dicarbonyl SOA doubles the SOA contribution to WSOC aerosol at all altitudes. Observed and simulated correlations of WSOC aerosol with other chemical variables measured aboard the aircraft suggest a major SOA source in the free troposphere compatible with the dicarbonyl mechanism.
\end{abstract}

(c) 2008 Elsevier Ltd. All rights reserved.

\section{Introduction}

Secondary organic aerosol (SOA) is produced in the atmosphere by oxidation of volatile organic compounds (VOCs) (Kanakidou et al., 2005). It is present in large concentrations throughout the troposphere (Zhang et al., 2007), yet its sources and composition remain highly uncertain. In previous work (Fu et al., 2008), we presented a global simulation of atmospheric glyoxal and methylglyoxal, and showed that these dicarbonyls could represent a significant global source of SOA through their irreversible uptake by cloud and aqueous aerosols. Here we explore the potential contribution of this mechanism to ambient concentrations of

\footnotetext{
* Corresponding author. Present address: Department of Civil and Structural Engineering, The Hong Kong Polytechnic University, Hung Hom, Kowloon, Hong Kong. Tel.: +852 2766 4489; fax: +852 23346389.

E-mail address: cetmfu@polyu.edu.hk (T.-M. Fu).
}

organic carbon $(\mathrm{OC})$ aerosol measured from surface and aircraft over eastern North America during the International Consortium for Atmospheric Research on Transport and Transformation (ICARTT) field program in summer 2004 (Fehsenfeld et al., 2006).

The standard mechanism used to describe SOA production in models involves reversible partitioning of semi-volatile oxidation products of VOCs onto preexisting organic particles (Pankow, 1994a,b; Odum et al., 1996). A number of global and regional models have used this approach to simulate SOA formation from oxidation of isoprene, terpenes, and aromatics, using laboratory data to constrain partitioning coefficients (e.g., Chung and Seinfeld, 2002; Tsigaridis and Kanakidou, 2003; Lack et al., 2004; Liao et al., 2007; McKeen et al., 2007; Henze et al., 2008). These simulations tend to underestimate the observed SOA (Heald et al., 2005; Volkamer et al., 2006; McKeen et al., 2007). Atmospheric observations indicate that (1) the ratio of SOA mass relative to total organic aerosol mass increases with air mass age (Zhang et al., 2007), and that (2) SOA concentrations are often correlated with sulfate 
produced in clouds (e.g., Yu et al., 2005; Zhang et al., 2005; Sorooshian et al., 2006; Kleinman et al., 2007; Lanz et al., 2007; Williams et al., 2007; Cottrell et al., 2008). These findings suggest that an irreversible SOA formation mechanism, possibly involving the aqueous phase, is missing from current models.

Uptake of dicarbonyl compounds by aqueous particles could provide such a mechanism. Glyoxal and methylglyoxal, the two smallest dicarbonyls, are high-yield oxidation products of many biogenic and anthropogenic VOCs (Fu et al., 2008; Myriokefalitakis et al., 2008; Volkamer et al., 2008). Chamber experiments by Schweitzer et al. (1998) and Liggio et al. (2005a,b) indicate irreversible first-order uptake of glyoxal by aqueous particles with a reactive uptake coefficient $\gamma \sim 10^{-3}$. A similar reaction probability has been measured for methylglyoxal in acidic solutions (Zhao et al., 2006). Once in the aqueous phase, the dicarbonyls may oxidize to form organic acids (e.g., Ervens et al., 2004, 2008; Lim et al., 2005; Warneck, 2005; Carlton et al., 2006, 2007; Sorooshian et al., 2006), oligomerize (e.g., Schweitzer et al., 1998; Kalberer et al., 2004; Liggio et al., 2005a,b; Hastings et al., 2005; Zhao et al., 2006; Loeffler et al., 2006), or oxidize to form organic acids which then oligomerize (Altieri et al., 2006, 2008). Volkamer et al.(2007) showed that SOA formation by glyoxal could account for the missing SOA source, as well as the missing gaseous glyoxal sink in Mexico City.

Considerable uncertainty remains regarding the mechanism of SOA formation by dicarbonyls. Kroll et al. (2005) found the uptake of glyoxal by aqueous aerosols to be reversible, with no significant SOA production. Volkamer et al. (2008) and Corrigan et al. (2008) both observed large growth when particles are exposed to glyoxal, but could not conclude as to whether the process is reversible. Questions also remain as to whether this pathway is acid-catalyzed (e.g., Liggio et al., 2005a), whether the oligomer formation may be reversible in dilute solutions (e.g., Altieri et al., 2006), and whether further aqueous oxidation to $\mathrm{CO}_{2}$ may pose a significant SOA sink (Ervens et al., 2008). Additional SOA formation mechanisms not involving the aqueous phase may also be important (e.g., Herndon et al., 2008).

Measurements of water-soluble organic carbon (WSOC) aerosol aboard the NOAA WP3 aircraft during the ICARTT field program offer an opportunity to evaluate the potential contribution of a dicarbonyl formation pathway. The aircraft made extensive gas phase and aerosol chemical measurements up to $6 \mathrm{~km}$ over eastern North America in July-August 2004. WSOC aerosol measurements aboard the aircraft were made with the Particle-Into-Liquid Sampler (PILS) (Sullivan et al., 2006). Ship-based measurements off the New England coast during ICARTT found that WSOC accounted on average for $55 \%$ of total OC aerosol (de Gouw et al., 2008). McKeen et al. (2007) examined the $\mathrm{PM}_{2.5}$ (particulate matter $<2.5 \mu \mathrm{m}$ ) concentrations forecasts in seven regional air quality models during ICARTT. They found that the organic component of $\mathrm{PM}_{2.5}$ was underpredicted by a factor of 2 compared to WSOC measurements aboard the WP3 aircraft, and concluded that the differences were likely due to underestimation of SOA.

The large ensemble of chemical data available aboard the WP3 aircraft during ICARTT allows for correlation of WSOC aerosol with chemical tracers of various sources. Sullivan et al. (2006) found that WSOC aerosol was strongly correlated with $\mathrm{CO}$ in the boundary layer, although this does not distinguish between anthropogenic or biogenic sources on a regional scale (Heald et al., 2006). The WSOC aerosol enhancement ratio relative to $\mathrm{CO}$ in urban plumes increased with air mass age, suggesting secondary production and a possible contribution from aromatics (Sullivan et al., 2006; de Gouw et al., 2008). In the free troposphere (above $2 \mathrm{~km}$ ), multivariate regression by Heald et al. (2006) showed that the observed WSOC aerosol was most correlated with methanol in combination with sulfate, nitric acid, and toluene, suggesting aqueous-phase SOA formation involving both anthropogenic and biogenic precursors. Additional measurements by Sorooshian et al. (2006) on a separate aircraft platform during ICARTT indicated high correlations between particulate sulfate and particulate oxalate (an aqueous-phase oxidation product of dicarbonyls) in clouds, suggesting an aqueous-phase pathway for SOA formation. Using a regional model, Carlton et al. (2008) recently simulated in-cloud SOA production from water-soluble glyoxal and methylglyoxal by applying stoichiometric yields based on laboratory studies. They compared the model OC with WSOC measurements aboard the WP3 aircraft during five flights; they found improved agreements when the in-cloud SOA source was added, particularly in clouds.

\section{Model description}

We simulate OC aerosol for the ICARTT period using the GEOSChem global 3-D chemical transport model (version 7.3.6; www.as. harvard.edu/chemistry/trop/geos). The simulation is conducted from January to August 2004; the first six months initialize the model and we focus on the July-August ICARTT period. GEOS-Chem is driven by assimilated meteorological data from the Goddard Earth Observing System (GEOS-4) of the NASA Global Modeling and Assimilation Office (Bey et al., 2001). Our simulation is conducted with $2^{\circ}$ latitude $\times 2.5^{\circ}$ longitude resolution and 30 vertical layers, including four layers below $2 \mathrm{~km}$ and four layers between 2 and $6 \mathrm{~km}$. GEOS-Chem contains a detailed $\mathrm{O}_{3}-\mathrm{NO}_{x}-\mathrm{VOC}$-aerosol chemical mechanism and has been applied previously to simulate ICARTT observations of a number of chemical species (e.g., Heald et al., 2006; Hudman et al., 2008; Millet et al., 2008).

Of particular relevance for our work is the previous GEOS-Chem simulation of OC aerosol during ICARTT by Heald et al. (2006). We use the same simulation as theirs except that we include SOA formation by the dicarbonyls pathway, whereas they only considered the standard approach involving reversible partitioning of the semi-volatile oxidation products of isoprene and terpenes. Henze et al. (2008) simulated the semi-volatile SOA produced from aromatics in GEOS-Chem but found that the contribution was small outside of urban air.

The air masses sampled during ICARTT were occasionally influenced by boreal fires in Alaska and western Canada. We use the daily fire emission inventory for summer 2004 by Turquety et al. (2007) based on burnt area reports and MODIS fire hot spots. The emission factor for OC aerosol from fires is assumed to be $9.7 \mathrm{~g}$ per $\mathrm{kg}$ dry matter (Hobbs et al., 1996), resulting in $1.4 \mathrm{Tg} \mathrm{C} \mathrm{OC}$ aerosol emitted from Alaskan and western Canadian fires for July-August 2004. 40\% of these emissions are released in the boundary layer, and $60 \%$ in the free troposphere above with even vertical distribution up to $5 \mathrm{~km}$ (Leung et al., 2007). Primary emission of OC aerosol from anthropogenic sources (including fossil fuel and biofuel use) is taken from Park et al. (2003) as constrained by measurements at continental U.S. surface sites from the Interagency Monitoring of Protected Visual Environments (IMPROVE) program. Total anthropogenic OC emission over eastern North America (domain of Fig. 1 ) was $0.17 \mathrm{Tg} C$ for July-August 2004 (30\% from fossil fuel use and 70\% from biofuel use). Our estimate is approximately twice the amount estimated by Bond et al. (2004), but the later may be too low by a factor of two (Park et al., 2006). There was no significant open fire burning over eastern U.S. during the ICARTT period.

We assume that freshly emitted $O C$ from open fire and all anthropogenic sources (including fossil fuel and biofuel use) is 50\% water-soluble and that the water-insoluble fraction is converted to water-soluble in the atmosphere with an e-folding lifetime of 1.2 days (Cooke et al., 1999; Park et al., 2005). Kondo et al. (2007) showed that OC freshly emitted from fossil fuel sources is largely water-insoluble, so our estimated primary anthropogenic OC contribution to WSOC should be considered as an upper estimate. 

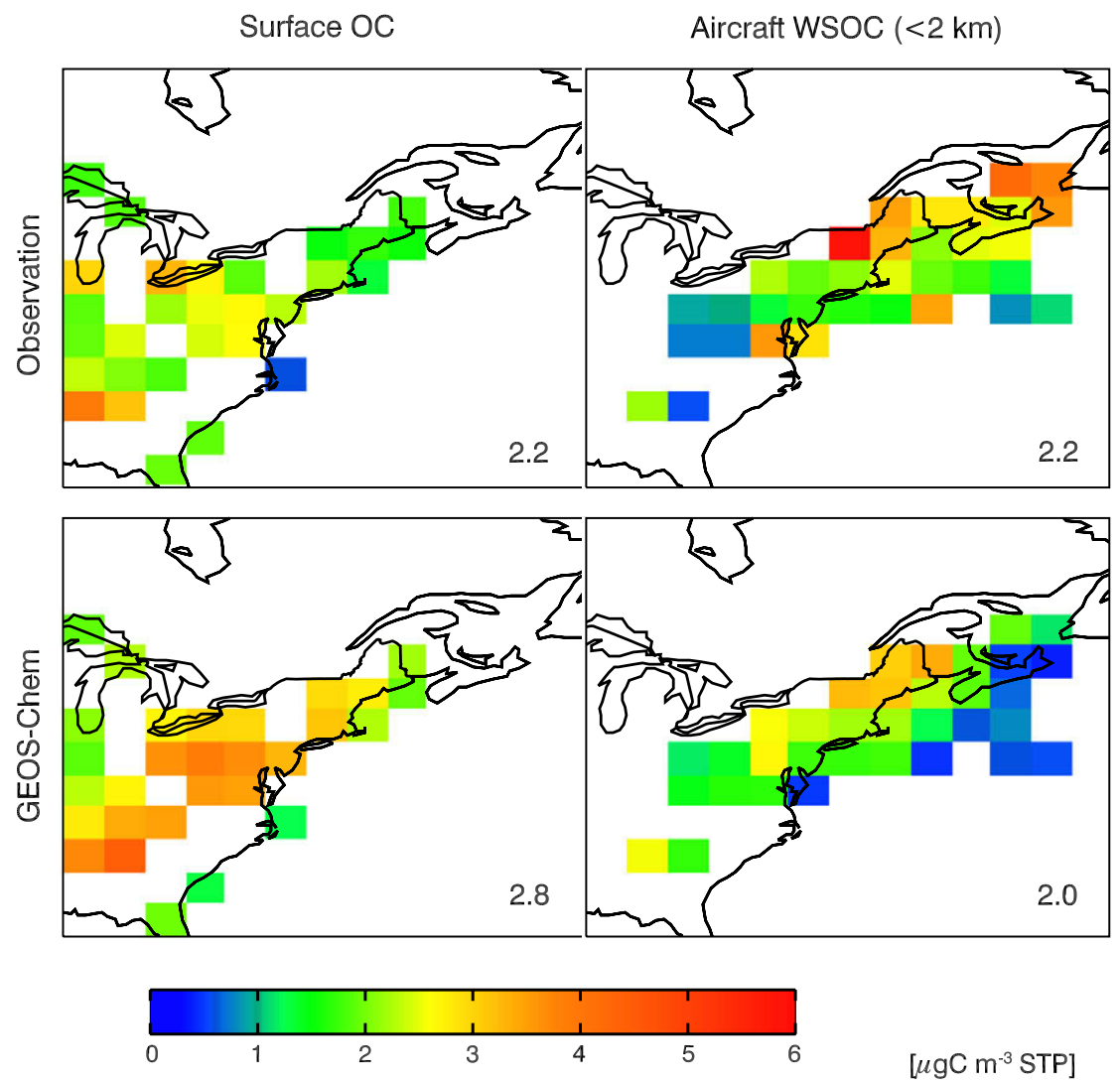

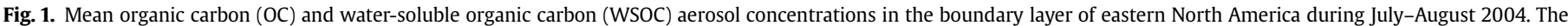

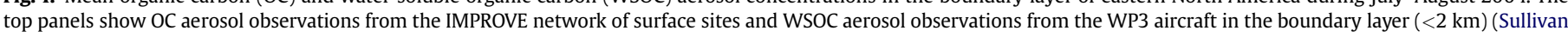

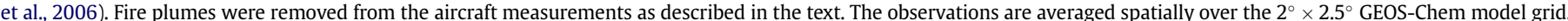

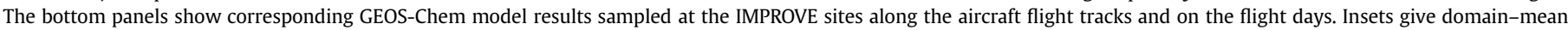
concentrations.

Heald et al. (2006) previously compared their simulation to the ICARTT WSOC aerosol observations of Sullivan et al. (2006). They assumed $80 \%$ of the semi-volatile SOA to be water-soluble (Chung and Seinfeld, 2002) and also assumed a conversion factor of 1.4 between total organic mass and carbon mass for semi-volatile SOA. Outside of fire plumes, the mean observed concentrations were $2.2 \mu \mathrm{g} \mathrm{C} \mathrm{m}^{-3}$ in the boundary layer $(<2 \mathrm{~km})$ and $0.9 \mu \mathrm{g} \mathrm{C} \mathrm{m}^{-3}$ in the free troposphere $(2-6 \mathrm{~km})$. Their corresponding mean model values were $1.3 \mu \mathrm{g} \mathrm{C} \mathrm{m}^{-3}$ (boundary layer) and $0.7 \mu \mathrm{g} \mathrm{C} \mathrm{m}^{-3}$ (free troposphere). Source attribution of model WSOC aerosol in the boundary layer was $48 \%$ from fuel emissions, $19 \%$ from fire emissions, and 33\% from biogenic SOA. In the free troposphere it was $22 \%$ from fuel emissions, $42 \%$ from fire emissions, and 36\% from biogenic SOA. Heald et al. (2006) attributed their model underestimate at all altitudes to missing SOA formation. Their SOA conversion factor of 1.4 is typical of urban aerosol, and a more

Table 1

Sources of glyoxal and methylglyoxal over eastern North America ${ }^{\mathrm{a}}$

\begin{tabular}{|c|c|c|c|c|c|c|c|c|}
\hline \multirow[t]{2}{*}{ Precursor } & \multicolumn{4}{|c|}{ Emission $^{\mathrm{b}}(\mathrm{Gg})$} & \multicolumn{2}{|c|}{ Glyoxal production } & \multicolumn{2}{|c|}{ Methylglyoxal production } \\
\hline & $\begin{array}{l}\text { Fossil fuel } \\
\text { and industry }\end{array}$ & Biofuel & $\begin{array}{l}\text { Vegetation } \\
\text { and soil }\end{array}$ & Total & $\begin{array}{l}\text { Molar yield } \\
(\%)\end{array}$ & $\begin{array}{l}\text { Production } \\
(\mathrm{Gg})\end{array}$ & $\begin{array}{l}\text { Molar } \\
\text { yield (\%) }\end{array}$ & $\begin{array}{l}\text { Production } \\
(\mathrm{Gg})\end{array}$ \\
\hline Isoprene & - & - & 3700 & 3700 & 8.6 & 280 & 32 & 1300 \\
\hline Acetylene & 21 & 2.7 & - & 24 & 64 & 34 & - & - \\
\hline Monoterpenes & - & - & 2800 & 2800 & 2.6 & 30 & 3.7 & 54 \\
\hline Acetone (primary) ${ }^{c}$ & 32 & 0.036 & 280 & 320 & - & - & 11 & 43 \\
\hline$>C_{2}$ alkenes & 110 & 7.1 & 110 & 230 & - & - & 7.5 & 30 \\
\hline$>C_{3}$ alkanes & 790 & 0.77 & - & 790 & - & - & 2.6 & 26 \\
\hline Methylbutenol & - & - & 550 & 550 & 6.1 & 23 & 4.5 & 21 \\
\hline Propane & 150 & 0.89 & - & 160 & - & - & 8.2 & 21 \\
\hline Ethylene & 38 & 2.4 & 88 & 130 & 7.2 & 19 & - & - \\
\hline Toluene & 98 & 1.0 & - & 99 & 16 & 10 & 12 & 9.6 \\
\hline Xylenes & 81 & 0.47 & - & 81 & 16 & 7.0 & 23 & 13 \\
\hline Benzene & 24 & 1.7 & - & 26 & 25 & 4.9 & - & - \\
\hline Total source & & & & & & 400 & & 1500 \\
\hline
\end{tabular}

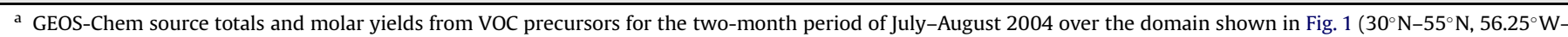
$\left.88.75^{\circ} \mathrm{W}\right)$. Budgets for the VOC precursors are also shown.

b Emissions from open biomass burning over eastern North America during July-August 2004 are negligible for all species of interest.

c The source from secondary acetone produced by atmospheric oxidation of VOCs is accounted for in the budgets of these VOCs. 
appropriate value for non-urban aerosol is 2.1 (Bae et al., 2006). Heald et al. (2006) also had an initialization error with zero SOA at the beginning of the simulation, which caused their simulated SOA to be too low by $50 \%$ but had little impact on the spatial distribution and vertical gradient. We corrected this error and used a mass conversion factor of 2.1 for semi-volatile SOA in what follows. The two corrections have canceling effects so that our simulated semivolatile SOA concentrations are essentially identical to those presented by Heald et al. (2006).

Our model representation of gas-phase dicarbonyl chemistry and irreversible uptake by aqueous particles to form SOA is as described in Fu et al. (2008). Table 1 summarizes the dicarbonyl sources over eastern North America during July-August 2004. Simulated surface gas-phase dicarbonyl concentrations over eastern U.S. are typically $10-100 \mathrm{ppt}$, consistent with in situ measurements (Fu et al., 2008). Total glyoxal production is $400 \mathrm{Gg}$, with largest contribution from isoprene (68\%), followed by acetylene $(8 \%)$ and monoterpenes (7\%). Total methylglyoxal production is $1500 \mathrm{Gg}$, mainly from isoprene $(85 \%)$ with minor contributions from monoterpenes (4\%) and acetone (3\%). In terms of source types, glyoxal is $84 \%$ biogenic and $16 \%$ anthropogenic. Methylglyoxal is $94 \%$ biogenic and $6 \%$ anthropogenic.

SOA formation from glyoxal and methylglyoxal is represented in the model as a first-order reactive uptake by aqueous particles including clouds, with a reactive uptake coefficient $\gamma=2.9 \times 10^{-3}$ based on the laboratory data of Liggio et al. (2005b) and Zhao et al. (2006). Aerosol surface area is calculated in GEOS-Chem using relative humidity-dependent effective radii applied to the mass concentrations (Martin et al., 2003). Cloud droplet surface area is calculated using liquid water contents derived from local GEOS-4 cloud optical depths and assuming effective droplet radii of $10 \mu \mathrm{m}$ for maritime clouds and $6 \mu \mathrm{m}$ for continental clouds. The dominant sink for both glyoxal and methylglyoxal is gas-phase photolysis, followed by losses of comparable magnitude to gas-phase oxidation by $\mathrm{OH}$ and SOA formation. For eastern North America during JulyAugust 2004, SOA formation accounts for $19 \%$ of glyoxal loss and $14 \%$ of methylglyoxal loss, and takes place almost entirely in low (1-3 km) clouds (98\%). For the domain in Fig. 1, the total SOA produced during July-August 2004 by glyoxal and methylglyoxal is $30 \mathrm{GgC}$ and $100 \mathrm{GgC}$, respectively. Overall $92 \%$ of the SOA produced by dicarbonyls is biogenic. We assume that SOA from dicarbonyls is $100 \%$ water-soluble.

We assume that the dicarbonyl SOA is additive to the semivolatile reversible SOA simulated by the standard approach, and we include both in our model. There is some experimental support for this assumption. The gas-aerosol partitioning coefficients used in the standard approach were obtained from chamber studies conducted at very low relative humidity (e.g., Kroll et al., 2005, 2006), where aqueous uptake would not occur. Also, Kroll et al. (2006) and Surratt et al. (2006) observed that the reversible SOA growth from isoprene oxidation follows methacrolein oxidation but not methylvinylketone oxidation. Since methylvinylketone is a larger source of both dicarbonyls than methacrolein, the reversible SOA is likely to be produced by a chemical pathway not involving the dicarbonyls.

\section{Simulation of observed organic aerosol concentrations}

Fig. 1 compares model results to the mean OC aerosol concentrations measured at 45 IMPROVE surface sites in the eastern U.S. in July-August 2004, as well as to the WSOC aerosol concentrations measured by the WP3 aircraft in the boundary layer $(<2 \mathrm{~km})$. Here
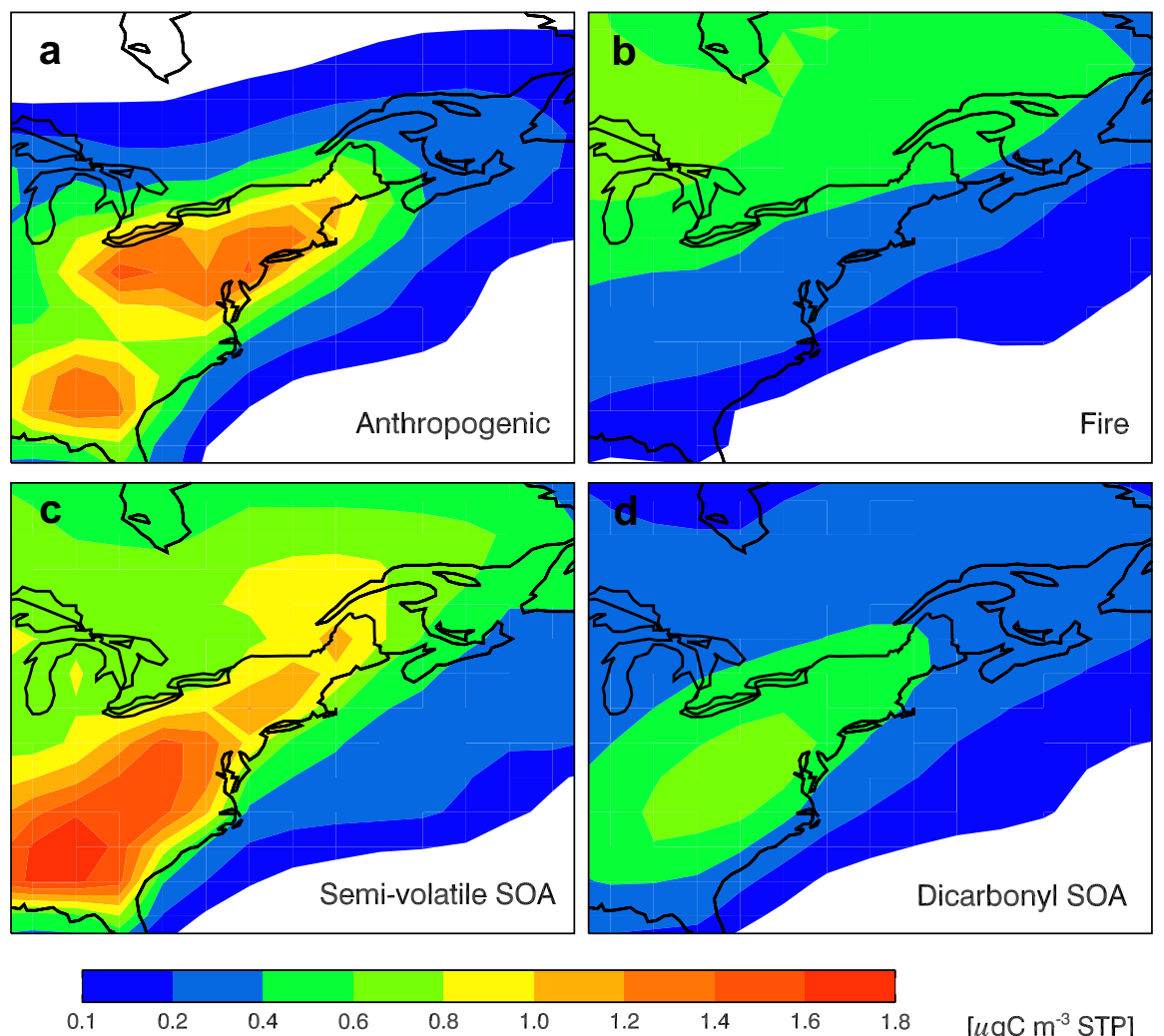

[ $\left.\mu \mathrm{gC} \mathrm{m} \mathrm{m}^{-3} \mathrm{STP}\right]$

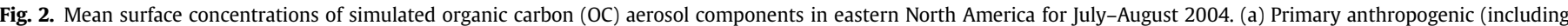

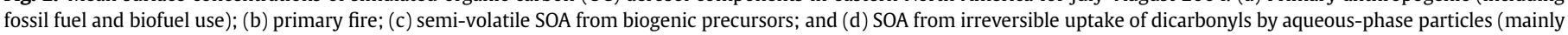
in clouds). 
and elsewhere, all OC aerosol concentrations are expressed in $\mu \mathrm{g} \mathrm{C} \mathrm{m}^{-3}$ at standard conditions of temperature and pressure (STP).

The IMPROVE network measures OC aerosol $(<2.5 \mu$ m diameter $)$ by a thermal/optical reflectance method and reports 24 -h average concentrations every third day (Malm et al., 1994). WSOC aerosol $(<1 \mu \mathrm{m}$ diameter) was measured aboard the aircraft every $3 \mathrm{~s}$ by the PILS coupled to a Total Organic Carbon (TOC) analyzer, with a denuder to eliminate positive bias from organic gas adsorption (Sullivan et al., 2006). Biomass burning plumes are removed from the aircraft data by excluding periods with measured acetonitrile $>225$ ppt, following Heald et al. (2006). This filter removes 7\% and $14 \%$ of the aircraft WSOC aerosol measurements in the boundary layer and in the free troposphere, respectively. We also exclude periods where acetonitrile measurements are not available, removing an additional $13 \%$ and $9 \%$ of aircraft WSOC measurements in the boundary layer and in the free troposphere, respectively. The model is sampled along the aircraft flight track and at $1 \mathrm{~min}$ intervals during flight times. All observation and model data are averaged to the model grid $\left(2^{\circ} \times 2.5^{\circ}\right)$ for comparison.

Surface OC aerosol concentrations measured by IMPROVE average $2.2 \pm 0.7 \mu \mathrm{g} \mathrm{C} \mathrm{m}^{-3}$ over the eastern U.S. domain of Fig. 1, with little apparent regional gradient. Model OC aerosol concentrations sampled at IMPROVE sites similarly show little regional gradient and average $2.8 \pm 0.8 \mu \mathrm{g} \mathrm{Cm}^{-3}, 27 \%$ higher than the IMPROVE observations. Model sources of OC aerosol for the ensemble of IMPROVE sites include 33\% from fuel combustion (primary), 12\% from fires (primary), 38\% from semi-volatile SOA, and $17 \%$ from dicarbonyl SOA. Yu et al. (2007) estimated the primary portion of OC aerosol measured at IMPROVE sites using modeled primary elemental carbon (EC) to OC ratios and measured EC concentrations. They found that $48 \%$ of OC aerosol in summer at eastern U.S. IMPROVE sites comes from primary sources, consistent with our result. However, recent work by Docherty et al. (2008) suggested that the method used by Yu et al. (2007) may overestimate the primary OC contribution. On a total mass basis, Zhang et al. (2007) showed that $95 \%$ of organic aerosol at rural areas is likely secondary. That fraction decreases to approximately $76 \%$ on a carbon mass basis (Kondo et al., 2007), high than our finding.

Fig. 2 shows the relative contributions of the different sources to surface OC aerosol concentrations in the model. The relative lack of spatial structure in OC concentrations in the eastern U.S. reflects compensating gradients from different sources. Anthropogenic primary OC aerosol is highest in the Midwest and Mid-Atlantic region, reflecting fossil fuel combustion, and also shows a secondary maximum in the Southeast from biofuel use. SOA is highest in the Southeast, reflecting biogenic sources, and fire influence is greatest in the North, due to transport from Alaska and NW Canada. The distribution of dicarbonyl SOA is shifted northward relative to that of semi-volatile SOA, reflecting the distribution of cloud cover.

The WSOC aircraft observations in Fig. 1 show a regional average of $2.2 \pm 1.2 \mu \mathrm{g} \mathrm{C} \mathrm{m}^{-3}$ in the boundary layer, consistent with IMPROVE, but with higher spatial variability and a Northeast maximum not observed by IMPROVE. The model sampled on the aircraft flight days averages $2.0 \pm 1.2 \mu \mathrm{g} \mathrm{Cm}^{-3}$, matching the observed variability and the high values over New England, although it still underestimates the high values observed north of Nova Scotia.

Fig. 3 shows the simulated components of WSOC aerosol as sampled along the flight tracks in the boundary layer. Simulated WSOC aerosol includes comparable contributions from anthropogenic OC aerosol (27\%), fire OC aerosol (18\%), semi-volatile SOA (28\%) and dicarbonyl SOA (27\%). The model attributes the high observed WSOC in the Northeast to preferential sampling of urban
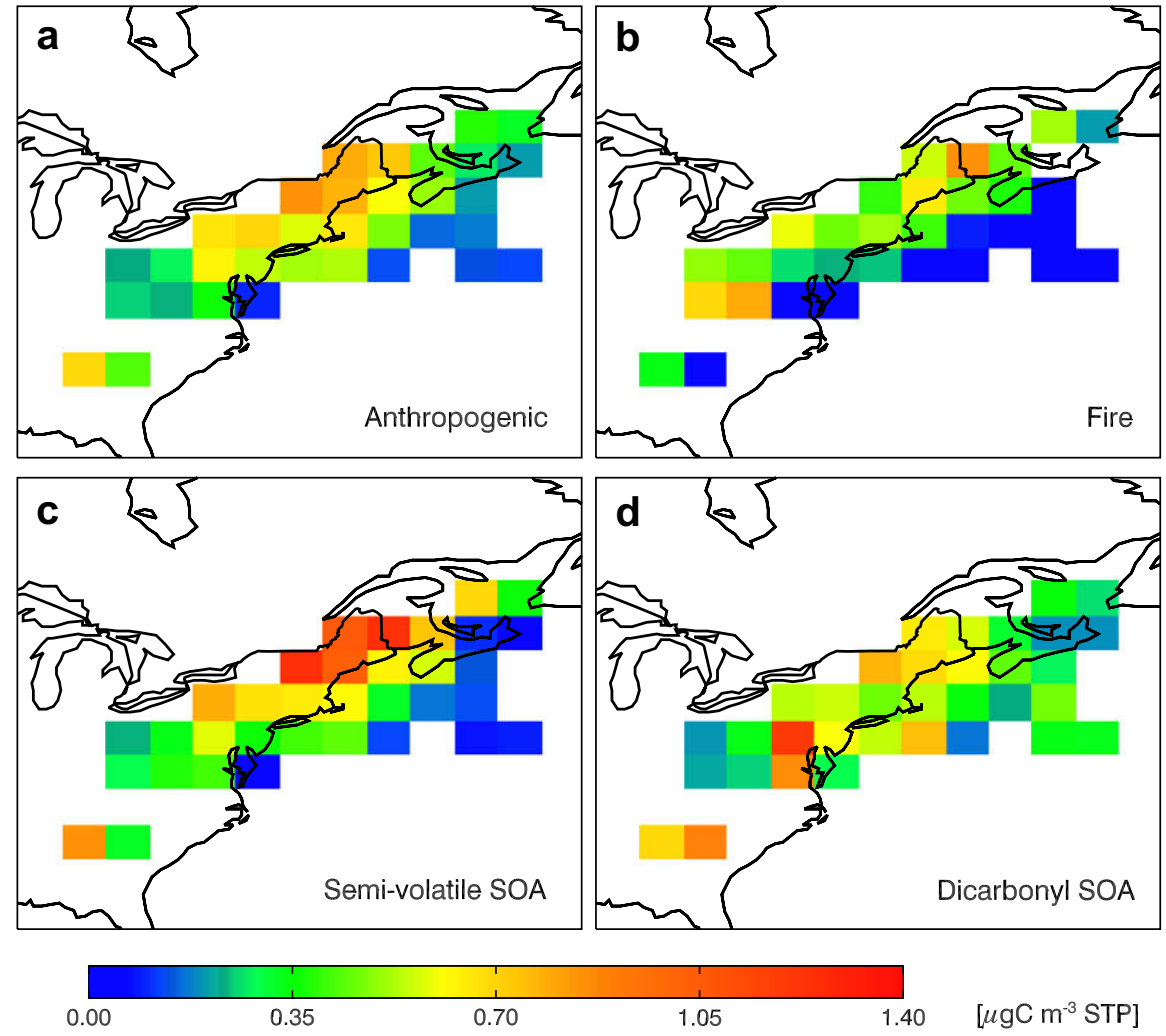

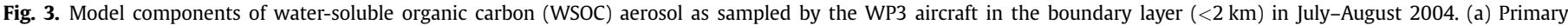

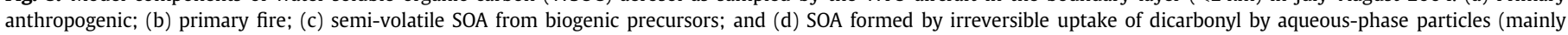
clouds). The model was sampled along the aircraft flight tracks and at the flight times. Fire plumes were removed as described in the text. 
a

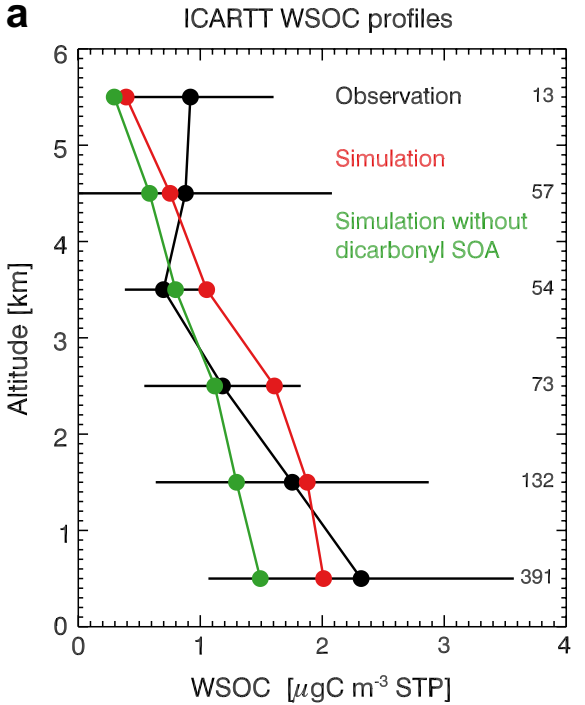

b Simulated WSOC components

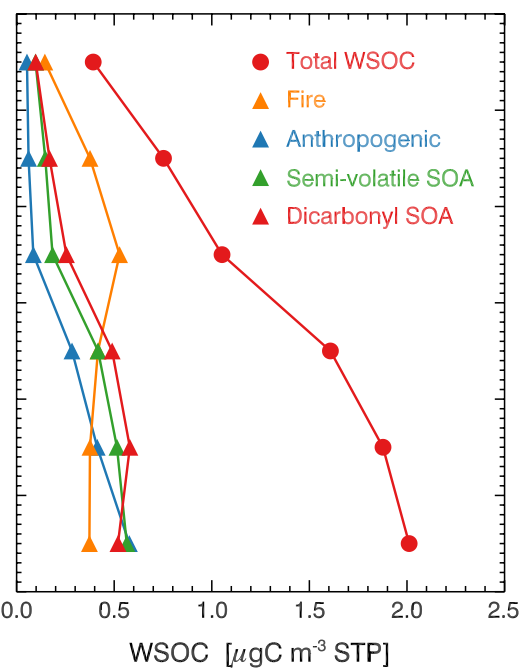

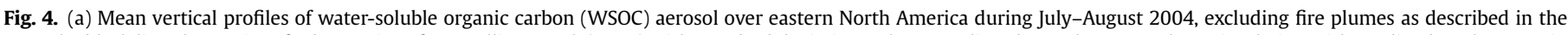

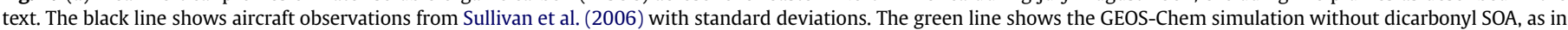

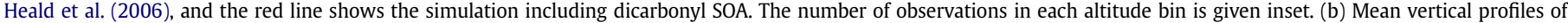

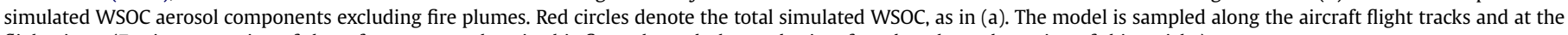
flight times (For interpretation of the references to colour in this figure legend, the reader is referred to the web version of this article.).

plumes and North American outflow by the aircraft (Fehsenfeld et al., 2006; Sullivan et al., 2006). Dicarbonyl SOA contribution is more prominent in aircraft WSOC compared to IMPROVE OC, due in part to the exclusion of water-insoluble OC components in the WSOC measurements and in part to cloud influences. The WSOC concentration gradient between land and ocean is smaller in the observation than in our model, in part due to the preferential sampling of offshore urban plumes (Neuman et al., 2006). It may also indicate large SOA formation via an irreversible mechanism, as simulated dicarbonyl SOA show a smaller gradient between land and ocean compared to other OC aerosol sources.

Fig. 4 shows the mean vertical profile of WSOC aerosol observed by the aircraft (excluding fire plumes as described above), and compares to the corresponding model simulation and individual model WSOC components. Observed concentrations decrease slowly with altitude, averaging $2.2 \pm 1.2 \mu \mathrm{g} \mathrm{C} \mathrm{m}^{-3}$ in the boundary layer $(<2 \mathrm{~km})$ and $0.9 \pm 0.8 \mu \mathrm{g} \mathrm{C} \mathrm{m}^{-3}$ in the free troposphere $(2-$ $6 \mathrm{~km}$ ). Heald et al. (2006) previously pointed out that this vertical gradient is much weaker than would be expected from a soluble aerosol with a surface source, implying a combination of fire influence and secondary production in the free troposphere. Model WSOC aerosol concentrations in the free troposphere average $1.1 \pm 1.0 \mu \mathrm{g} \mathrm{C} \mathrm{m}^{-3}$, consistent with the observations. Source attribution for the model WSOC in the free troposphere includes $13 \%$ primary anthropogenic, $37 \%$ from fires, $23 \%$ from semi-volatile SOA, and $27 \%$ from dicarbonyl SOA. Dicarbonyl and semi-volatile SOA make contributions of similar magnitude at all altitudes. Inclusion of dicarbonyl SOA in the model corrects the low bias previously found in the Heald et al. (2006) simulation.

\section{Correlations of WSOC aerosol with other chemical variables}

We now compare the correlations of WSOC aerosol with other chemical variables, to see in particular if the addition of dicarbonyl SOA improves the representation of observed WSOC sources. Sullivan et al. (2006) showed that observed WSOC aerosol in the boundary layer was highly correlated with $\mathrm{CO}(R=0.74)$, which they attributed to an anthropogenic source of WSOC. However,
Heald et al. (2006) found in their simulation that biogenic SOA is also correlated with model CO from Hudman et al. (2008) $(R=0.57)$. They showed that the observed dWSOC/dCO slope in the boundary layer ( $37 \mu \mathrm{g} \mathrm{C} \mathrm{m}^{-3} \mathrm{ppm}^{-1}$ ) could be reproduced in their model by increasing their reversible biogenic SOA by a factor of 4 .

Fig. 5 compares the WSOC-CO relationship in the observations and in our model. The correlation coefficient between observed and simulated boundary layer WSOC aerosol is $R=0.42$. Including

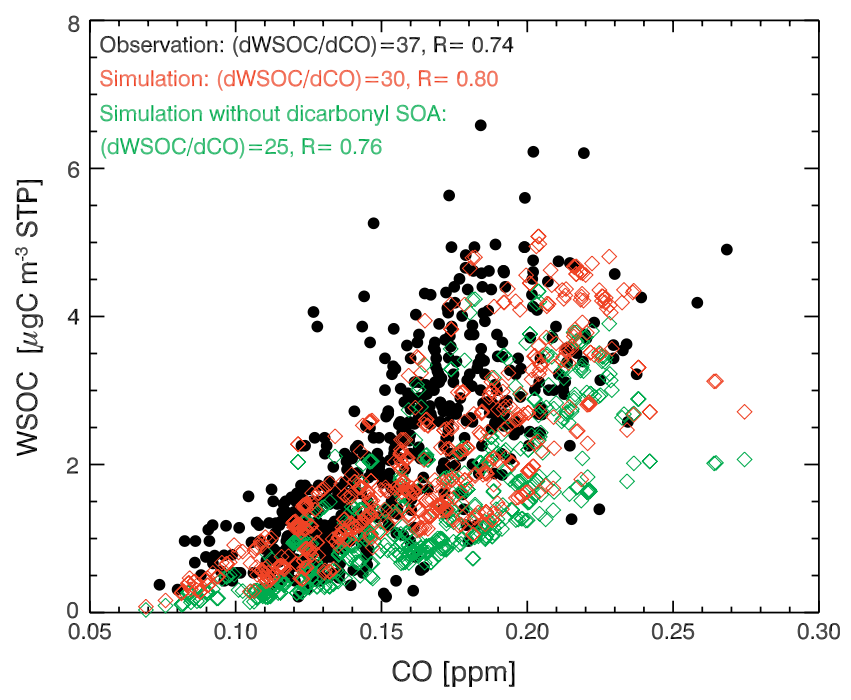

Fig. 5. Relationship between water-soluble organic carbon (WSOC) aerosol and CO concentrations measured aboard the WP3 aircraft (black circles) in the boundary layer (0-2 km). Also shown are simulated boundary layer WSOC aerosol and CO concentrations including dicarbonyl SOA (red) and excluding dicarbonyl SOA (green). Fire plumes were removed on the basis of acetonitrile measurements. The aircraft data are averaged over the model spatial and temporal resolution $\left(2^{\circ} \times 2.5^{\circ}, 15 \mathrm{~min}\right)$, and the model is sampled along the aircraft flight tracks. Shown inset are the WSOC and CO correlations $(R)$ and enhancement ratios (dWSOC/dCO), calculated by the reduced major axis method and assuming background concentrations of $\mathrm{WSOC}=0.75 \mu \mathrm{g} \mathrm{m}^{-3}$ STP and $\mathrm{CO}=0.121 \mathrm{ppm}$ following Sullivan et al. (2006) (For interpretation of the references to colour in this figure legend, the reader is referred to the web version of this article.). 
dicarbonyl SOA improves the correlation with model CO in the boundary layer $(R=0.80)$, and shows an improved dWSOC/dCO slope of $30 \mu \mathrm{g} \mathrm{C} \mathrm{m}^{-3} \mathrm{ppm}^{-1}$ (reduced major axis regression), compared to $25 \mu \mathrm{g} \mathrm{C} \mathrm{m}^{-3} \mathrm{ppm}^{-1}$ in the model without dicarbonyl SOA.

In the free troposphere and outside of biomass burning plumes, Heald et al. (2006) previously examined the correlations of observed WSOC aerosol against selected chemical variables measured aboard the WP3 aircraft during ICARTT. Bivariate regressions showed the strongest correlations with methanol and sulfate $(R=0.35-0.40)$. Trivariate regressions showed the strongest correlations for methanol in combination with sulfate, nitric acid, or toluene ( $R=0.50-0.55)$, suggesting aqueous-phase SOA formation involving both anthropogenic and biogenic precursors.

We examine here the correlations of observed and simulated free tropospheric WSOC aerosol with the full ensemble of chemical variables measured on the aircraft. Heald et al. (2006) did not previously examine the model values. Compared to Heald et al. (2006), our analysis also uses a stricter biomass burning filter (removing both samples with acetonitrile $>225$ ppt and samples with no acetonitrile measurements), and averages of measurements over the model spatial and temporal resolution $\left(2^{\circ} \times 2.5^{\circ}\right.$, $15 \mathrm{~min}$ ) for comparison of observed and model correlations. The ten strongest correlations $(R>0.38)$ are shown in Fig. 6 . All of these correlations are based on more than 70 data points, are not driven by outliers, and are significant at the $95 \%$ confidence level.

We find that observed WSOC aerosol in the free troposphere is most strongly correlated with MoPAN (methoxyperoxyacetyl nitrate, $\left.\mathrm{CH}_{3} \mathrm{OCH}_{2} \mathrm{C}(\mathrm{O}) \mathrm{O}_{2} \mathrm{NO}_{2}\right)$ and $\mathrm{NO}_{y}(R>0.5)$, followed in order by nitric acid, ammonium, methyl bromide, sulfate, and toluene $(R>0.4)$. MoPAN is thought to be mostly anthropogenic (Flocke, F., personal communication, 2008), although elevated levels of MoPAN have been found in biomass burning plumes during ICARTT (Flocke et al., 2004). Methyl bromide also has a strong biomass burning source (Warwick et al., 2006), although the enhancements in the Alaskan forest fire plumes observed during ICARTT were very small. Correlations with $\mathrm{NO}_{y}$, nitric acid, methyl nitrate, and PAN point to a photochemical origin for WSOC aerosol. Correlation with sulfate suggests SOA production in the aqueous phase, while correlation with toluene suggests an anthropogenic contribution. Correlation of observed WSOC aerosol against methanol is significant though not as prominent as found in Heald et al. (2006). The observed correlations point to multiple sources for the $\mathrm{OC}$ aerosol in the free troposphere, qualitatively consistent with the model picture of Fig. 4. The WSOC-CO correlation in the free troposphere $(R=0.3)$ is much weaker than that in the boundary layer, likely reflecting the scavenging of primary OC aerosol during transport to the free troposphere.

We compare in Fig. 6 the correlations of simulated WSOC aerosol, with or without SOA production from dicarbonyls, against the measured chemical variables in the free troposphere. Heald et al. (2006) found that their simulated WSOC aerosol did not reproduce the variance in the free tropospheric observations, and we find the same here $(R=0.14)$. We find that this is due in part to model fire plumes that are mispositioned and hence not filtered out by observations of acetonitrile. The model has more success in reproducing the observed correlations of WSOC aerosol with chemical variables, as shown in Fig. 6. Inclusion of dicarbonyl SOA contributes to this success, as we see in Fig. 6 that the correlations in the model without dicarbonyl SOA are degraded (dark green vs. red). However, increasing the source of semivolatile SOA instead of adding dicarbonyl SOA would achieve the same result (light green vs. red). Thus the observed WSOC aerosol correlations in the free troposphere are consistent with a large SOA source but do not allow us to distinguish between dicarbonyl and reversible sources.

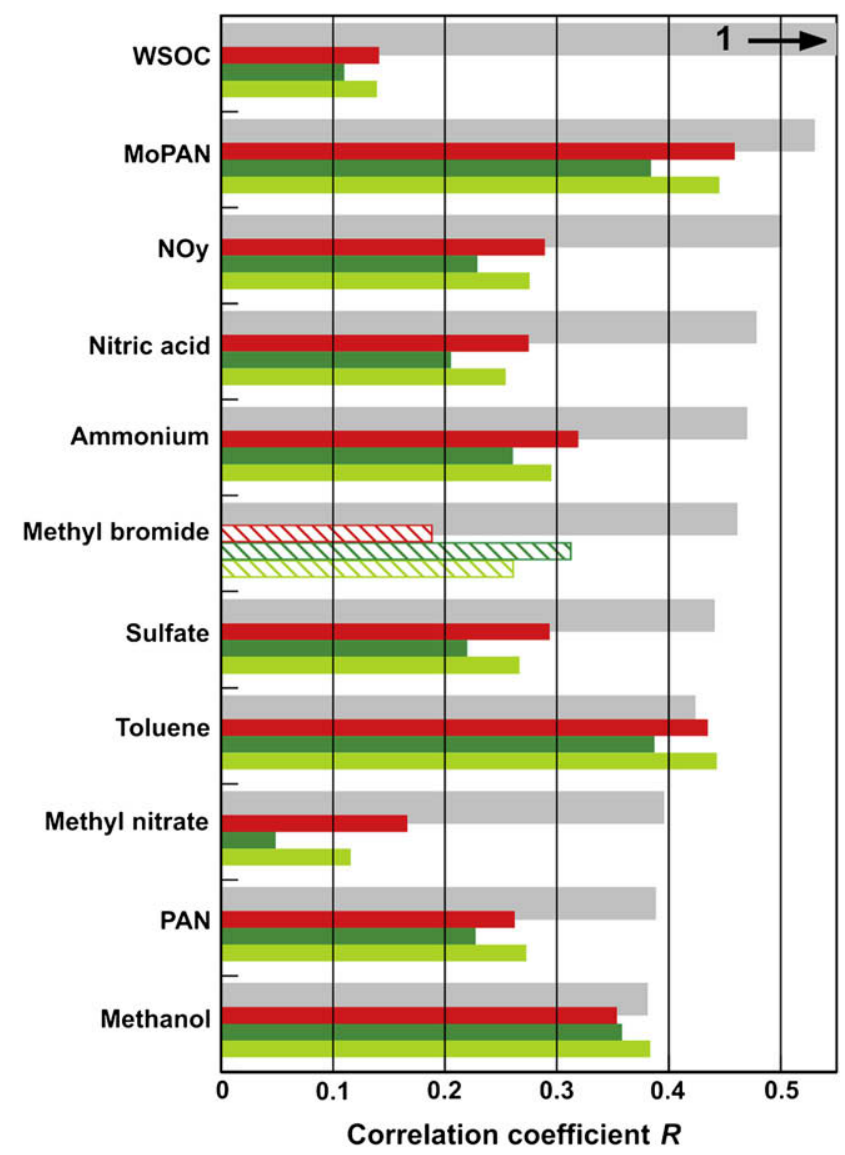

Fig. 6. Correlation coefficients between water-soluble organic carbon (WSOC) aerosol concentrations and other chemical variables measured aboard the WP3 aircraft in the free troposphere $(2-6 \mathrm{~km})$ during ICARTT, for the filtered data set excluding fire plumes. Correlations are shown for observed WSOC aerosol (grey), simulated WSOC aerosol (red), simulated WSOC aerosol excluding SOA production from dicarbonyls (dark green), and simulated WSOC aerosol including doubled standard reversible SOA from biogenic precursors but excluding dicarbonyl SOA (light green). Only species with correlation coefficients against observed WSOC aerosol $R>0.38$ are shown. Model correlation with measured methyl bromide is negative (hatched bars). MoPAN: methoxyperoxyacetyl nitrate; PAN: peroxyacetyl nitrate. Observed $\mathrm{NO}_{y}$ was calculated by summing individual measurements of reactive nitrogen species $\left(\mathrm{NO}_{y}=\mathrm{NO}+\mathrm{NO}_{2}+\mathrm{HNO}_{3}+\mathrm{PANs}+\mathrm{NO}_{3}+2 \times \mathrm{N}_{2} \mathrm{O}_{5}\right)$ (For interpretation of the references to colour in this figure legend, the reader is referred to the web version of this article.).

\section{Conclusions}

We used surface and aircraft observations of organic carbon (OC) aerosol over eastern North America during the ICARTT campaign of summer 2004 to explore the importance of a new secondary organic aerosol (SOA) formation pathway via irreversible uptake of dicarbonyl gases (glyoxal and methylglyoxal) by aqueous particles. Observed concentrations were compared to simulations with the GEOS-Chem global 3-D model including standard sources of OC aerosol as well as the dicarbonyl SOA pathway. Both dicarbonyls are predominantly produced from biogenic VOCs (mainly isoprene), with minor contributions from anthropogenic VOCs. Dicarbonyl SOA formation is represented by a reactive uptake coefficient $\gamma=2.9 \times 10^{-3}$ (Liggio et al., 2005b), which competes with gas-phase photolysis and oxidation as a sink for the dicarbonyls. Because of this competition, we find that dicarbonyl SOA formation takes place mainly in clouds where liquid water contents are large.

Surface measurements at the IMPROVE network of rural surface sites in the eastern U.S. average $2.2 \pm 0.7 \mu \mathrm{g} \mathrm{C} \mathrm{m}^{-3}$ for the 
July-August 2004 period, exhibiting little spatial variability. The model has a slightly higher mean concentration and reproduces the weak variability $\left(2.8 \pm 0.8 \mu \mathrm{g} \mathrm{C} \mathrm{m}^{-3}\right)$; dicarbonyl SOA makes a $17 \%$ contribution to the mean. The weak spatial variability reflects in the model the superimposition of contributions from biogenic, anthropogenic, and fire sources having distinct and compensating regional patterns.

Aircraft measurements of water-soluble organic carbon (WSOC) aerosol average $2.2 \pm 1.2 \mu \mathrm{g} \mathrm{C} \mathrm{m}^{-3}$ in the boundary layer of the ICARTT flight region, highest in the Northeast and more variable than the IMPROVE data. The model sampled along the flight tracks and on the flight days shows a mean WSOC aerosol concentration of $2.0 \pm 1.2 \mu \mathrm{g} \mathrm{C} \mathrm{m}^{-3}$, consistent with the aircraft, and reproduces the Northeast maximum which reflects the choice of flight days to target pollution plumes and U.S. outflow to the North Atlantic. Simulated WSOC aerosol concentrations in the boundary layer include comparable contributions from anthropogenic OC aerosol (27\%), biomass burning OC aerosol (18\%), semi-volatile SOA $(28 \%)$ and dicarbonyl SOA (27\%). In the free troposphere and outside of fire plumes, observed WSOC aerosol concentrations average $0.9 \pm 0.8 \mu \mathrm{g} \mathrm{C} \mathrm{m}^{-3}$. The corresponding model concentration is $1.1 \pm 1.0 \mu \mathrm{g} \mathrm{C} \mathrm{m}^{-3}$, including contributions from anthropogenic OC aerosol (13\%), biomass burning OC aerosol (37\%), semi-volatile SOA (23\%) and dicarbonyl SOA (27\%). Inclusion of dicarbonyl SOA doubles the SOA contribution to simulated WSOC aerosol at all altitudes.

We reproduce the strong correlation of WSOC aerosol with CO observed in the boundary layer (Sullivan et al., 2006) and show that it is compatible with a biogenic SOA source via uptake of dicarbonyls. In the free troposphere and outside of biomass burning plumes, Heald et al. (2006) previously found that the observed WSOC aerosol was most correlated with methanol in combination with sulfate, nitric acid, and toluene, suggesting aqueous-phase SOA formation involving both anthropogenic and biogenic precursors. We report here also strong correlations with methyl bromide and peroxyacetyl nitrates, indicative of fire influence. Including the dicarbonyl SOA source improves the correlations of model WSOC aerosol against measured chemical variables in the free troposphere, although the same improvement could be achieved by increasing the semi-volatile SOA source from the standard reversible mechanism.

\section{Acknowledgments} (EPRI).

This work was funded by the Electric Power Research Institute

\section{References}

Altieri, K.E., Carlton, A.G., Lim, H.-J., Turpin, B.J., Seitzinger, S.P., 2006. Evidence for oligomer formation in clouds: reactions of isoprene oxidation products. Environmental Science and Technology 40, 4956-4960. doi:10.1021/es052170n.

Altieri, K.E., Seitzinger, S.P., Carlton, A.G., Turpin, B.J., Klein, G.C., Marshall, A.G., 2008. Oligomers formed through in-cloud methylglyoxal reactions: chemical composition, properties, and mechanisms investigated by ultra-high resolution FT-ICR mass spectrometry. Atmospheric Environment 42 (7), 1476-1490. doi:10.1016/j.atmosenv.2007.11.015.

Bae, M.-S., Demerjian, K.L., Schwab, J.J., 2006. Seasonal estimation of organic mass to organic carbon in $\mathrm{PM}_{2.5}$ at rural and urban locations in New York state. Atmospheric Environment 40 (39), 7467-7479. doi:10.1016/j.atmosenv. 2006.07.008.

Bey, I., Jacob, D.J., Yantosca, R.M., Logan, J.A., Field, B., Fiore, A.M., Li, Q., Liu, H., Mickley, L.J., Schultz, M., 2001. Global modeling of tropospheric chemistry with assimilated meteorology: model description and evaluation. Journal of Geophysical Research 106, 23,073-23,096.

Bond, T.C., Streets, D.G., Yarber, K.F., Nelson, S.M., Woo, J.-H., Klimont, Z., 2004. A technology-based global inventory of black and organic carbon emissions from combustion. Journal of Geophysical Research 109, D14203. doi:10.1029/ 2003JD003697.
Carlton, A.G., Turpin, B.J., Lim, H.-J., Altieri, K.E., Seitzinger, S., 2006. Link between isoprene and secondary organic aerosol (SOA): pyruvic acid oxidation yields low volatility organic acids in clouds. Geophysical Research Letter 33, L06822. doi:10.1029/2005GL025374.

Carlton, A.G., Turpin, B.J., Altieri, K.E., Seitzinger, S., Reff, A., Lin, H.-J., Ervens, B., 2007. Atmospheric oxalic acid and SOA production from glyoxal: results of aqueous photooxidation experiments. Atmospheric Environment 41 (35), 7588-7602. doi:10.1016/j.atmosenv.2007.05.035.

Carlton, A.G., Turpin, B.J., Altieri, K.E., Seitzinger, S.P., Mathur, R., Roselle, S.J., Weber, R.J., 2008. CMAQ model performance enhanced when in-cloud secondary organic aerosol is included: comparisons of organic carbon predictions with measurements. Environmental Science and Technology 42, 87988802. doi: $10.1021 /$ es801192n.

Chung, S.H., Seinfeld, J.H., 2002. Global distribution and climate forcing of carbonaceous aerosols. Journal of Geophysical Research 107 (D19), 4407. doi:10.1027/ 2001JD001397.

Cooke, W.F., Liousse, C., Cachier, H., Feichter, J., 1999. Construction of a $1^{\circ} \times 1^{\circ}$ fossil fuel emission data set for carbonaceous aerosol and implementation and radiative impact in the ECHAM-4 model. Journal of Geophysical Research 104, 22,137-22,162.

Corrigan, A.L., Hanley, S.W., de Haan, D.O., 2008. Uptake of glyoxal by organic and inorganic aerosol. Environmental Science and Technology 42, 4428-4433. doi:10.1021/es7032394.

Cottrell, L.D., Griffin, R.J., Jimenez, J.L., Zhang, Q., Ulbrich, I., Ziemba, L.D., Beckman, P.J, Sive, B.C., Talbot, R.W., 2008. Submicron particles at Thompson Farm during ICARTT measured using aerosol mass spectrometry. Journal of Geophysical Research 113, D08212. doi:10.1029/2007JD009192.

Docherty, K.S., et al., 2008. Apportionment of primary and secondary organic aerosols in southern California during the 2005 Study of Organic Aerosols in Riverside (SOAR-1). Environmental Science and Technology 42 (20), 7655-7662. doi:10.1021/es8008116.

Ervens, B., Carlton, A.G., Turpin, B.J., Altieri, K.E., Kreidenweis, S.M., Feingold, G., 2008. Secondary organic aerosol yields from cloud-processing of isoprene oxidation products. Geophysical Research Letters 35, L02816. doi:10.1029/ 2007 GL031828.

Ervens, B., Feingold, G., Frost, G.J., Kreidenweis, S.M., 2004. A modeling study of aqueous production of dicarboxylic acids: 1 . Chemical pathways and speciated organic mass production. Journal of Geophysical Research 109, D15205. doi:10.1027/2003JD004387.

Fehsenfeld, F.C., et al., 2006. International Consortium for Atmospheric Research on Transport and Transformation (ICARTT): North America to Europe-overview of the 2004 summer field study. Journal of Geophysical Research 111, D23S01. doi:10.1029/2006JD007829.

Flocke, F., et al., 2004. Fast time resolution airborne measurements of PANs during the New England Air Quality Study 2004 Intensive, presented at AGU 2004 Fall meeting.

Fu, T.-M., Jacob, D.J., Wittrock, F., Burrows, J.P., Vrekoussis, M., Henze, D.K., 2008. Global budgets of atmospheric glyoxal and methylglyoxal, and implications for formation of secondary organic aerosols. Journal of Geophysical Research 113, D15303. doi:10.1029/2007JD009505.

de Gouw, J.A., et al., 2008. Sources of particulate matter in the northeastern United States in summer: 1. Direct emissions and secondary formation of organic matter in urban plumes. Journal of Geophysical Research 113, D08301. doi:10.1027/2007JD009243.

Hastings, W.P., Koehler, C.A., Bailey, E.L., de Haan, D.O., 2005. Secondary organic aerosol formation by glyoxal hydration and oligomer formation: humidity effects and equilibrium shifts during analysis. Environmental Science and Technology 39, 8728-8735. doi:10.1021/es0504461.

Heald, C.L., Jacob, D.J., Park, R.J., Russell, L.M., Huebert, B.J., Seinfeld, J.H., Liao, H., Weber, R.J., 2005. A large organic aerosol source in the free troposphere missing from current models. Geophysical Research Letter 32, L18809. doi:10.1029/ 2005 GL023831.

Heald, C.L., et al., 2006. Concentrations and sources of organic carbon aerosol in the free troposphere over North America. Journal of Geophysical Research 111, D23S47. doi:10.1029/2006JD007705.

Henze, D.K., Seinfeld, J.H., Ng, N.L., Kroll, J.H., Fu, T.-M., Heald, C.L., 2008. Global modeling of secondary organic aerosol formation from aromatic hydrocarbons: high- vs. low-yield pathways. Atmospheric Chemistry and Physics 8, 2405-2421.

Herndon, S.C., et al., 2008. Correlation of secondary organic aerosol with odd oxygen in Mexico City. Geophysical Research Letters 35, L15804. doi:10.1029/ 2008GL034058.

Hobbs, P.V., Reid, J.S., Herring, J.A., Nance, J.D., Weiss, R.E., Ross, J.L., Hegg, D.A., Ottmar, R.D., Liousse, C., 1996. Particle and trace-gas measurements in the smoke from prescribed burns of forest products in the Pacific Northwest. In: Levine, J.S. (Ed.), Biomass Burning and Global Change. MIT Press, Cambridge, Massachusetts, pp. 697-715.

Hudman, R.C., Murray, L.T., Jacob, D.J., Millet, D.B., Turquety, S., Wu, S., Blake, D.R., Goldstein, A.H., Holloway, J., Sachse, G.W., 2008. Biogenic versus anthropogenic sources of CO in the United States. Geophysical Research Letter 35, L04801. doi:10.1029/2007GL032393.

Kanakidou, M., et al., 2005. Organic aerosol and global climate modelling: a review. Atmospheric Chemistry and Physics 5 (4), 1053-1123.

Kalberer, M., et al., 2004. Identification of polymers as major components of atmospheric organic aerosols. Science 303, 1659-1662. 
Kleinman, L.I., et al., 2007. Aircraft observations of aerosol composition and ageing in New England and Mid-Atlantic States during the summer 2002 New England Air Quality Study field campaign. Journal of Geophysical Research 112, D09310. doi:10.1029/2006JD007786.

Kondo, Y., Miyazaki, Y., Takegawa, N., Miyakawa, T., Weber, R.J., Jimenez, J.L., Zhang, Q., Worsnop, D.R., 2007. Oxygenated and water-soluble organic aerosols in Tokyo. Journal of Geophysical Research 112, D01203. doi:10.1029/ 2006JD007056.

Kroll, J.H., Ng, N.L., Murphy, S.M., Flagan, R.C., Seinfeld, J.H., 2006. Secondary organic aerosol from isoprene photooxidation. Environmental Science and Technology 40, 1869-1877. doi:10.1021/es0524301.

Kroll, J.H., Ng, N.L., Murphy, S.M., Varutbangkul, V., Flagan, R.C., Seinfeld, J.H., 2005. Chamber studies of secondary organic aerosol growth by reactive uptake of simple carbonyl compounds. Journal of Geophysical Research 110, D23207. doi:10.1029/2005JD006004.

Lack, D.A., Tie, X.X., Bofinger, N.D., Wiegand, A.N., Madronich, S., 2004. Seasonal variability of secondary organic aerosol: a global modeling study. Journal of Geophysical Research 109, D03203. doi:10.1029/2003JD003418.

Lanz, V.A., Alfarra, M.R., Baltensperger, U., Buchmann, B., Hueglin, C., Prév̂ot, A.S.H., 2007. Source apportionment of submicron organic aerosols at an urban site by factor analytical modelling of aerosol mass spectra. Atmospheric Chemistry and Physics 7, 1503-1522.

Leung, F.-Y., Logan, J.A., Park, R., Hyer, E., Kasischke, E., Streets, D., Yuganov, L., 2007. Impacts of biomass burning in the boreal forests on tropospheric chemistry and the sensitivity of model results to injection height. Journal of Geophysical Research 112, D10313. doi:10.1029/2006JD008132.

Liao, H., Henze, D.K., Seinfeld, J.H., Wu, S., Mickley, L.J., 2007. Biogenic secondary organic aerosol over the United States: comparison of climatological simulations with observations. Journal of Geophysical Research 112, D06201. doi:10.1029/2006JD007813.

Liggio, J., Li, S.-M., McLaren, R., 2005a. Heterogeneous Reactions of glyoxal on particulate matter: identification of acetals and sulfate esters. Environmental Science and Technology 39, 1532-1541. doi:10.1021/es048375.

Liggio, J., Li, S.-M., McLaren, R., 2005b. Reactive uptake of glyoxal by particulate matter. Journal of Geophysical Research 110, D10304. doi:10.1029/ 2004JD005113.

Lim, H.-J., Carlton, A.G., Turpin, B.J., 2005. Isoprene forms secondary organic aerosol through cloud processing: model simulations. Environmental Science and Technology 39, 4441-4446. doi:10.1021/es048039h.

Loeffler, K.W., Koehler, C.A., Paul, N.M., de Haan, D.O., 2006. Oligomer formation in evaporating aqueous glyoxal and methyl glyoxal solutions. Environmental Science and Technology 40,6318-6323. doi:10.1021/es060810w.

Malm, W.C., Sisler, J.F., Huffman, D., Eldred, R.A., Cahill, T.A., 1994. Spatial and seasonal trends in particle concentration and optical extinction in the United States. Journal of Geophysical Research 99, 1347-1370.

Martin, R.V., Jacob, D.J., Yantosca, R.M., Chin, M., Ginoux, P., 2003. Global and regional decreases in tropospheric oxidants from photochemical effects of aerosols. Journal of Geophysical Research 108 (D3), 4097. doi:10.1029/ 2002JD002622.

McKeen, S., et al., 2007. Evaluation of several $\mathrm{PM}_{2.5}$ forecast models using data collected during the ICARTT/NEAQS 2004 field study. Journal of Geophysical Research 112, D10S20. doi:10.1029/2006JD007608.

Millet, D.B., et al., 2008. New constraints on terrestrial and oceanic sources of atmospheric methanol. Atmospheric Chemistry and Physics 8, 6887-6905.

Myriokefalitakis, S., Vrekoussis, M., Tsigaridis, K., Wittrock, F., Richter, A., Brühl, C., Volkamer, R., Burrows, J.P., Kanakidou, M., 2008. The influence of natural and anthropogenic secondary sources on the glyoxal global distribution. Atmospheric Chemistry and Physics Discussions 8, 1673-1708.

Neuman, J.A., Parish, D.D., Trainer, M., Ryerson, T.B., Holloway, J.S., Nowak, J.B., Swanson, A., Flocke, F., Roberts, J.M., Brown, S.S., Stark, H., Sommariva, R., Stohl, A., Peltier, R., Weber, R., Wollny, A.G., Sueper, D.T., Hubler, G., Fehsenfeld, F.C., 2006. Reactive nitrogen transport and photochemistry in urban plumes over the North Atlantic Ocean. Journal of Geophysical Research 111, D23S54. doi:10.1029/2005JD007010.

Odum, J.R., Hoffmann, T., Bowman, F., Collins, D., Flagan, R.C., Seinfeld, J.H., 1996. Gas/particle partitioning and secondary organic aerosol yields. Environmental Science and Technology 30, 2580-2585.

Pankow, J.F., 1994a. An absorption model of gas/particle partitioning of organic compounds in the atmosphere. Atmospheric Environment 28, 185-188.

Pankow, J.F., 1994b. An absorption model of gas/particle partitioning involved in the formation of secondary organic aerosol. Atmospheric Environment 28, 189-193.
Park, R.J., Jacob, D.J., Chin, M., Martin, R.V., 2003. Sources of carbonaceous aerosols over the United States and implications for natural visibility. Journal of Geophysical Research 108 (D12), 4355. doi:10.1029/2002JD003190.

Park, R.J., Jacob, D.J., Kumar, N., Yantosca, R.M., 2006. Regional visibility statistics in the United States: natural and transboundary pollution influences, and implications for the Regional Haze Rule. Atmosphere Environment 40, 5405-5423. doi:10.1016/j.atmosenv.2006.04.059.

Park, R.J., et al., 2005. Export efficiency of black carbon aerosol in continental outflow: global implications. Journal of Geophysical Research 110, D11205. doi:10.1029/2004JD005432.

Schweitzer, F., Magi, L., Mirabel, P., George, C., 1998. Uptake rate measurements of methanesulfonic acid and glyoxal by aqueous droplets. Journal of Physical Chemistry A 102, 593-600.

Sorooshian, A., et al., 2006. Oxalic acid in clear and cloudy atmospheres: analysis of data from International Consortium for Atmospheric Research on Transport and Transformation 2004. Journal of Geophysical Research 111, D23S45. doi:10.1029/2005JD006880.

Sullivan, A.P., Peltier, R.E., Brock, C.A., de Gouw, J.A., Holloway, J.S., Warneke, C. Wollny, A.G., Weber, R.J., 2006. Airborne measurements of carbonaceous aerosol soluble in water over northeastern United States: method development and an investigation into water-soluble organic carbon sources. Journal of Geophysical Research 111, D23S46. doi:10.1029/2006JD007072.

Surratt, J.D. et al. 2006. Chemical composition of secondary organic aerosol formed from the photooxidation of isoprene. Journal of Physical Chemistry A 110 (31) 9665-9690. doi: $10.1021 / \mathrm{jp} 061734 \mathrm{~m}$.

Tsigaridis, K., Kanakidou, M., 2003. Global modeling of secondary organic aerosol in the troposphere: a sensitivity analysis. Atmospheric Chemistry and Physics 3 , 1849-1869.

Turquety, S., et al., 2007. Inventory of boreal fire emissions for North America in 2004: importance of peat burning and pyroconvective injection. Journal of Geophysical Research 112, D12S03. doi:10.1029/2006JD007281.

Volkamer, R., Jimenez, J.L., San Martini, F., Dzepina, K., Zhang, Q., Salcedo, D. Molina, L.T., Worsnop, D.R., Molina, M.J., 2006. Secondary organic aerosol formation from anthropogenic air pollution: rapid and higher than expected. Geophysical Research Letter 33, L17811. doi:10.1029/2006GL026899.

Volkamer, R., San Martini, F., Molina, L.T., Salcedo, D., Jimenex, J.L., Molina, M.J. 2007. A missing sink for gas-phase glyoxal in Mexico City: formation of secondary organic aerosol. Geophysical Research Letter 34, L19807. doi:10.1029| 2007GL030752.

Volkamer, R., Ziemann, P.J., Molina, M.J., 2008. Secondary organic aerosol formation from acetylene $\left(\mathrm{C}_{2} \mathrm{H}_{2}\right)$ : seed effect on SOA yields due to organic photochemistry in the aerosol aqueous phase. Atmospheric Chemistry and Physics Discussion 8 14841-14892.

Warneck, P., 2005. Multi-phase chemistry of $C_{2}$ and $C_{3}$ organic compounds in the marine atmosphere. Journal of Atmospheric Chemistry 51, 119-159. doi:10.1007/s10874-005-5984-7.

Warwick, N.J., Pyle, J.A., Shallcross, D.E., 2006. Global modeling of the atmospheric methyl bromide budget. Journal of Atmospheric Chemistry 54 (2) 133-159. doi:10.1007/s10874-006-9020-3.

Williams, B.J., et al., 2007. Chemical speciation of organic aerosol during the International Consortium for Atmospheric Research on Transport and Transformation 2004: results from in situ measurements. Journal of Geophysical Research 112, D10S26. doi:10.1029/2006JD007601.

Yu, J.Z., Huang, X.-F., Xu, J., Hu, M., 2005. When aerosol sulfate goes up, so does oxalate: implication for the formation mechanisms of oxalate. Environmental Science and Technology 38, 128-133. doi:10.1021/es049559f.

Yu, S., Bhave, P.V., Dennis, R.L., Mathur, R., 2007. Seasonal and regional variations of primary and secondary organic aerosols over the continental United States: semi-empirical estimates and model evaluation. Environmental Science and Technology 41, 4690-4697. doi:10.1021/es061535g.

Zhang, Q., Worsnop, D.R., Canagaratna, M.R., Jimenez, J.L., 2005. Hydrocarbon-like and oxygenated organic aerosols in Pittsburgh: insights into sources and processes of organic aerosols. Atmospheric Chemistry and Physics 5 3289-3311.

Zhang, Q, et al., 2007. Ubiquity and dominance of oxygenated species in organic aerosols in anthropogenically-influenced Northern Hemisphere midlatitudes. Geophysical Research Letter 34, L13801. doi:10.1029/2007GL029979.

Zhao, J., Levitt, N.P., Zhang, R.Y., Chen, J.M., 2006. Heterogeneous reactions of methylglyoxal in acidic media: implications for secondary organic aeroso formation. Environmental Science and Technology 40, 7682-7687. doi:10.1021 es060610k 